\title{
Evaluasi Struktur Gedung Control Room Pt. Perta Arun Gas Terhadap Beban Tsunami
}

\author{
Febri Fitrah $^{1}$, Purwandy Hasibuan ${ }^{2}$, Mahlil $^{3}$ \\ ${ }^{1}$ Mahasiswa, Jurusan Teknik Sipil,Universitas Syiah Kuala, Banda Aceh 23111, Indonesia \\ ${ }^{2,3}$ Jurusan Teknik Sipil, Universitas Syiah Kuala Banda Aceh 23111, Indonesia \\ *corresponding author, email :febrifitrah9@gmail.com
}

\begin{abstract}
The control room building belonging to PT. Perta Arun Gas was built by London Bechtel International Limited Company in 1976 with a composite structure design. This building is also located in the province of Aceh which is located on an active fault of the earth and is prone to earthquakes that will cause a tsunami. Therefore, it is necessary to evaluate the control room building to see the behavior of the structure due to tsunami loading using FEMA P646 regulations in 2012 and SNI 1727 in 2020 using ETABS software. This study aims to see the behavior of the structure due to tsunami loading on the control room building. The results showed that the analysis of the ratio of the capacity of all structural elements to the tsunami load for FEMA and SNI regulations showed that only column K1 with unsafe conditions consisted of 3 column elements with values > 1, namely 1.26 for FEMA and 1.04 for SNI. . The behavior of the structure in the form of level displacement and deviation between levels obtained from the two regulations is still safe from the $x$ and $y$ directions because it does not exceed the permitted limit.
\end{abstract}

Keywords: structural behavior, composite structure, FEMA, SNI, tsunami.

\begin{abstract}
Abstrak
Gedung control room milik PT. Perta Arun Gas dibangun oleh Perusahaan Bechtel International Limited London pada tahun 1976 dengan perencanaan struktur komposit. Gedung ini juga terletak di provinsi Aceh yang berada pada patahan-patahan aktif bumi dan rawan terhadap gempa bumi yang akan mengakibatkan tsunami. Oleh karena itu perlu dilakukan evaluasi terhadap gedung control room untuk melihat perilaku struktur akibat pembebanan dari beban tsunami menggunakan peraturan FEMA P646 tahun 2012 dan SNI 1727 tahun 2020 dengan menggunakan software ETABS. Penelitian ini bertujuan untuk melihat perilaku struktur akibat pembebanan tsunami terhadap Gedung control room. Adapun hasil penelitian menunjukkan analisa rasio kapasitas pada seluruh elemen struktur terhadap beban tsunami untuk peraturan FEMA dan SNI menunjukkan bahwa hanya kolom K1 dengan kondisi tidak aman yang berjumlah 3 elemen kolom dengan nilai >1, yaitu 1,26 untuk FEMA dan 1,04 untuk SNI. Perilaku struktur berupa story displacement dan story drift yang diperoleh dari kedua peraturan masih aman dari kedua arah $x$ dan y karena tidak melewati batas yang diizinkan.
\end{abstract}

Kata kunci: perilaku struktur, struktur komposit, FEMA, SNI, tsunami.

\section{Pendahuluan}

Gedung control room merupakan bangunan berlantai 3 dengan luas bangunan $266 \mathrm{~m} 2$ dan tinggi bangunan adalah $10,2 \mathrm{~m}$ yang terletak pada koordinat $5.229^{\circ}$ Lintang Utara dan $97.084^{\circ}$ Lintang Timur kota lhokseumawe yang dibangun pada tahun 1976 dengan ketinggian 6 meter dari muka air laut dan berjarak \pm 190 meter dari garis pantai. Struktur utama dari bangunan ini terdiri dari rangka portal baja yang dilapisi oleh beton. Lantai control room dibangun dengan balok baja dengan pelat beton bertulang. Struktur atap terdiri dari baja ringan yang mendukung baja deking[1].

Gedung control room ini diharapkan tahan terhadap beban tsunami yang timbul pada saat tsunami datang, Karena Gedung terletak di provinsi Aceh yang berada pada patahan-patahan aktif bumi dan rawan terhadap gempa bumi yang akan mengakibatkan tsunami. Salah satu bencana tsunami fenomenal yang terjadi di Indonesia adalah tsunami yang terjadi pada tahun 2004. Kejadian tersebut telah menewaskan korban jiwa yang tidak sedikit, tercatat sebanyak lebih dari 230 ribu jiwa yang meninggal saat bencana tersebut [2].

Journal of The Civil Engineering Student Vol. 3. No. 3, Desember 2021, Halaman 222-228
Oleh karena itu, berdasarkan permasalahan di atas perlu dilakukan evaluasi terhadap gedung untuk melihat perilaku struktur akibat pembebanan tsunami dengan menggunakan FEMA P646 tahun 2012 dan SNI 1727 tahun 2020 sebagai acuan untuk perhitungan beban tsunami dan membandingkan hasil tersebut menurut peraturan FEMA dan SNI. Penelitian ini bertujuan untuk melihat kapasitas elemen dan perilaku struktur akibat pembebanan tsunami terhadap Gedung control room. Manfaat dari penelitian ini adalah sebagai pertimbangan untuk bangunan yang berada pada zona rawan bencana yang akan dibangun untuk memperhitungkan beban tsunami pada perhitungan struktur bangunannya.

\section{Metodelogi Penelitian \\ 2.1 Objek Penelitian}

Objek penelitian ini adalah sebuah bangunan gedung control room milik PT. Perta Arun Gas. Bangunan tersebut merupakan bangunan berlantai dua dengan komponen struktur terdiri dari pondasi, kolom, balok, dinding geser dan pelat lantai. Struktur pondasi, dinding geser dan pelat lantai menggunakan beton bertulang, sedangkan struktur kolom dan balok 
menggunakan baja profil $\mathrm{H}$ dengan casing dari beton yang di lapisi oleh mesh 22-1010. Bangunan ini memiliki tinggi total $10,2 \mathrm{~m}$. Bentang lebar dan panjang maksimumnya adalah $14 \mathrm{~m}$ dan 19,9 m.

\subsection{Jenis dan Sumber Data}

Perencanaan ini menggunakan data primer dan data sekunder. Data primer adalah data yang diperoleh langsung dari survei lapangan pada gedung control room milik PT. Perta Arun Gas berupa data dimensi-dimensi elemen struktur bangunan. Data sekunder merupakan data yang diperoleh dari sumber atau instansi terkait dalam bentuk siap pakai. Data sekunder yang dipakai dalam penelitian ini berupa As built drawing control room yang diperoleh dari perpustakaan PT. PAG.

\subsection{Metode Analisi Data}

\subsubsection{Pembebanan Tsunami}

Pembebanan tsunami ini mengacu pada peraturan [3] dan [4] Gaya-gaya yang terdapat pada beban tsunami meliputi:

\section{Gaya Hidrostatik}

Gaya hidrostatik terjadi ketika air yang bergerak perlahan mengenai komponen struktur. Gaya hidrostatik ini biasanya penting untuk struktur-struktur yang panjang yang mana ketinggian air di satu sisi sangat berbeda dengan ketinggian air di sisi yang lainnya.

Pada [3] Gaya hidrostatik dapat dihitung dengan persamaan :

$$
F_{n}=p_{c} A_{w}=\frac{1}{2} \rho_{s} g b h_{m a k s}^{2}
$$

Sedangkan pada [4] gaya hidrostatik dapat dihitung dengan persamaan :

$$
F_{n}=\frac{1}{2} \rho_{s} b h_{m a k s}^{2}
$$

\section{Keterangan :}

$p_{c} \quad=$ tekanan hidrostatik $\left(\mathrm{N} / \mathrm{m}^{2}\right)$;

$A_{w} \quad=$ area dinding yang terkena air $\left(\mathrm{m}^{2}\right) ;$

$\rho_{s} \quad=$ massa jenis air tsunami (termasuk

sedimen) $\left(1100 \mathrm{~kg} / \mathrm{m}^{3}\right)$;

$\mathrm{g} \quad=$ percepatan gravitasi $\left(9,81 \mathrm{~m} / \operatorname{det}^{2}\right) ;$

$b \quad=$ lebar dinding $(\mathrm{m})$; dan

$h_{\text {maks }}=$ ketinggian air maksimum dari dasar dinding (m).

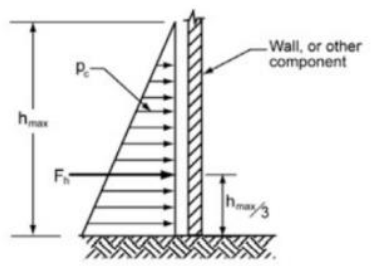

Gambar 1 Distribusi dan Resultan Gaya Hidrostatik Sumber : [3]

2. Gaya Hidrodinamik
Gaya hidrodinamik digunakan pada saat air mengalir disekeliling struktur bangunan. Gaya hidrodinamik ini dapat dihitung dengan persamaan sebagai berikut:

Pada [3] Gaya hidrostatik dapat dihitung dengan persamaan :

$F_{d}=\frac{1}{2} \rho_{s} C_{d} B\left(h u^{2}\right)_{m a k s}$

dimana,

$\left(h u^{2}\right)_{\text {maks }}=g R^{2}\left(0,125-0,235 \frac{z}{r}+0,11\left(\frac{z}{r}\right)^{2}\right)$

Sedangkan pada [4] gaya hidrostatik dapat dihitung dengan persamaan :

$F_{d}=\frac{1}{2} \rho_{s} l_{t s u} C_{d} B\left(h u^{2}\right)_{m a k s}$

Keterangan :

$C_{d}=$ koefisien seret $\left(C_{d}=2\right)$;

$\mathrm{B}=$ luasan struktur pada bidang normal arah aliran (m);

$\mathrm{h}=$ kedalaman aliran $(\mathrm{m})$; dan

$\mathrm{u}=$ kecepatan aliran pada lokasi struktur $(\mathrm{m} / \mathrm{det})$.

$\mathrm{g}=$ percepatan gravitasi $\left(9,81 \mathrm{~m} / \mathrm{det}^{2}\right)$;

$\mathrm{R}=$ ketinggian run-up desain $(\mathrm{m})$; dan

$\mathrm{z}=$ elevasi tanah pada dasar struktur $(\mathrm{m})$.

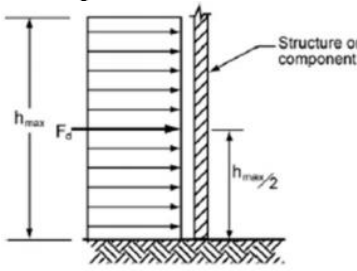

Gambar 2 Distribusi dan Resultan Gaya Hidrodinamik Sumber : [3]

\section{Gaya Tumbukan Debris}

Gaya tumbukan yang berasal hayutan puingpuing dapat menjadi penyebab kerusakan pada bangunan. Gaya ini diasumsikan hanya bekerja pada salah satu bagian struktur bangunan pada ketinggian muka air. Gaya tumbukan oleh puing hanyutan ini hanya terdapat pada [3] dan dapat diperkirakan dengan menggunakan persamaan berikut :

$F_{s}=1,3 u_{\text {maks }} \sqrt{k m_{d}(1+c)}$

Dimana,

$u_{\text {maks }}=\sqrt{\left(2 g R\left(1-\frac{z}{r}\right)\right)}$

Keterangan :

$\mathrm{U}_{\text {maks }}=$ kecepatan maksimum aliran yang membawa puing $(\mathrm{m} / \mathrm{det})$;

$\mathrm{M} \quad=$ massa puing $(\mathrm{kg})$;

$\mathrm{k}=$ kekerasan puing $(\mathrm{N} / \mathrm{m})$; dan

$\mathrm{c} \quad=$ koefisien masa hidrodinamik.

$\mathrm{R} \quad=$ ketinggian run-up desain (m); 


\section{Gaya Tahanan Debris}

Gaya tahanan debris yang disebabakan dari akumulasi hanyutan puing-puing yang tersangkut pada struktur dapat dianggap sebagai gaya hidrodinamik tambahan oleh puing yang tertahan pada permukaan depan struktur. Gaya tahanan debris ini hanya terdapat pada [3] dan dapat diperkirakan dengan menggunakan persamaan berikut :

$F_{d m}=\frac{1}{2} \rho_{s} C_{d} B_{d}\left(h u^{2}\right)_{m a k s}$

Keterangan :

$\mathrm{Bd}=$ lebar/luas permukaan puing (rekomendasi $\mathrm{Bd}=12 \mathrm{~m})$

\section{Beban Impak Puing}

Beban yang berasal dari puing-puing atau benda lain yang terbawa oleh tsunami desain yang menghantam struktur atau bagiannya. Beban impak puing ini hanya terdapat pada [4] dan dapat dihitung dengan persamaan sebagai berikut:

$F_{i}=l_{t s u} C_{o} F_{n i}$

Dimana,

$F_{n i}=U_{\max } \sqrt{k m}_{d}$

Keterangan :

$F_{n i}=$ gaya impak puing seketika $(\mathrm{kN})$

$\mathrm{C}_{\mathrm{o}}=$ koefisien orientasi $\left(\mathrm{C}_{\mathrm{o}}=0,65\right)$;

$l_{t s u}=$ faktor keutamaan untuk gaya tsunami $\left(l_{t s u}=1\right)$.

$U_{\max }=$ Kecepatan aliran maksimum di lokasi $(3 \mathrm{~m} / \mathrm{s})$

$k=$ Kekakuan efektif dari impak puing $(61300 \mathrm{kN} / \mathrm{m})$

$m_{d} \quad=$ Massa puing $(454 \mathrm{~kg})$

\subsubsection{Kombinasi Pembebanan Tsunami}

\section{FEMA P646 (2012)}

Kombinasi pembebanan tsunami berdasakan

[3] yaitu sebagai berikut:

$$
\begin{aligned}
& \mathrm{U}=1,2 \mathrm{D}+1,0 \mathrm{TS}+1,0 \mathrm{~L}_{\mathrm{REF}}+0,25 \mathrm{~L} \\
& \mathrm{U}=0,9 \mathrm{D}+1,0 \mathrm{TS}
\end{aligned}
$$

Dimana :

$\mathrm{U}$ = beban ultimit;

D = beban mati;

L = beban hidup;

TS = beban tsunami; dan

$\mathrm{L}_{\mathrm{REF}}=$ beban hidup untuk daerah yang terlindungi.

\section{SNI 1727:2020}

Kombinasi pembebanan tsunami berdasakan [4] yaitu sebagai berikut:

$$
\begin{aligned}
& 0,9 \mathrm{D}+\mathrm{F}_{\mathrm{TSU}}+\mathrm{H}_{\mathrm{TSU}} \\
& 0,9 \mathrm{D}+\mathrm{F}_{\mathrm{TSU}}+0,5 \mathrm{~L}+0.2 \mathrm{~S}+\mathrm{H}_{\mathrm{TSU}}
\end{aligned}
$$

Keterangan :

$F_{\mathrm{TSU}}=$ Beban tsunami

Journal of The Civil Engineering Student

Vol. 3. No. 3, Desember 2021, Halaman 222-228
$H_{T S U}=$ Beban yang disebabkan oleh tekanan fondasi lateral $\left(H_{T S U}=0,9\right)$

$\mathrm{D} \quad=$ Beban mati

$\mathrm{L} \quad=$ Beban hidup

$\mathrm{S} \quad=$ Beban salju

\subsubsection{Struktur Komposit}

Dalam komposit (composite) merupakan struktur yang terdiri dari dua material atau lebih dengan sifat bahan yang berbeda dan membentuk satu kesatuan sehingga menghasilkan sifat gabungan yang lebih baik. Perencanaan komposit mengasumsi bahwa baja dan beton bekerja sama dalam memikul beban yang bekerja, sehingga akan menghasilkan desain profil/elemen yang lebih ekonomis [5].

Ada dua tipe struktur komposit, yaitu :

1. Struktur komposit yang terbuat dari profil baja yang diberi selubung beton di sekelilingnya (kolom baja berselubung beton); dan

2. Struktur komposit terbuat dari penampang baja berongga (kolom baja berisikan beton).

Perencanaan struktur komposit baja beton

kolom dianalisis menggunakan ketentuan DFBK sesuai [6] Pasal I dengan menggunakan persamaan:

a. Kontrol kuat tekan

Kekuatan tekan desain komponen struktur komposit terbungkus beton yang dibebani secara aksial simetri ganda harus ditentukan untuk keadaan batas dari tekuk lentur berdasarkan kelangsingan komponen struktur sebagai berikut:

$$
\begin{array}{ll}
\text { Jika } \frac{P_{n o}}{P_{e}} \leq 2,25 & P_{n}=P_{n o}\left[0,658^{\frac{P_{n o}}{P_{e}}}\right] \\
\text { Jika } \frac{P_{n o}}{P_{e}}>2,25 & P_{n}=0,887 P_{e}
\end{array}
$$

Untuk mencari Pno digunakan persamaan :

$$
P_{n o}=f_{y} A_{s}+f_{y s r} A_{g r}+0,85 f_{c} A_{c}
$$

Rasio kapasitas aksial:

$$
\frac{P_{u}}{\phi_{c} P_{n}}<1
$$

b. Kontrol kuat lentur

Berdasarkan [6] pasal I3.2 dan pasal F2, kekuatan lentur tersedia dari komponen struktur terbungkus beton harus merupakan nilai terendah yang diperoleh sesuai dengan keadaan batas dari leleh (momen plastis) dan tekuk torsilateral.

Untuk komponen struktur yang memenuhi $L_{p} \leq L_{b} \leq L_{r}$ kuat nominal komponen struktur terhadap momen lentur adalah:

$M_{n}=c_{b}\left[M_{p}+\left(M_{p}-0,7 f_{y} S_{x}\right) \frac{\left(L_{b}-L_{p}\right)}{\left(L_{r}-L_{p}\right)}\right]$

Rasio kapasitas lentur :

$$
\frac{M_{u}}{\phi b M_{n}}<1
$$

c. Kontrol kuat geser 
Berdasarkan [6] pasal 14.1, kekuatan geser desain ditentukan berdasrkan persamaan berikut:

$$
V_{n}=0,6 f_{y} A_{w} C_{v}
$$

Untuk badan komponen struktur profil-Icanai panas dengan $h / t w \leq 2,24 \sqrt{E / f_{y}}$ :

$\phi_{v}=1,00(\mathrm{DFBK})$

$C_{v}=1,00$

Rasio kapasitas geser:

$$
\frac{V_{u}}{\phi_{v} V_{n}}<1
$$

d. Kontrol Interaksi Kuat Tekan dan Lentur Untuk komponen struktur komposit dibungkus beton dan komponen struktur komposit diisi beton dengan penampang kompak, interaksi gaya aksial dan lentur harus berdasarkan persamaan interaksi [6] pasal H1.1

$$
\begin{aligned}
& \frac{P r}{\phi P c} \geq 0,2 \Rightarrow \frac{P r}{\phi P c}+\frac{8}{9}\left(\frac{M r x}{M c x}+\frac{M r y}{M c y}\right) \leq 1 \\
& \frac{P r}{\phi P c}<0,2 \Rightarrow \frac{P r}{2 \phi P c}+\left(\frac{M r x}{M c x}+\frac{M r y}{M c y}\right) \leq 1
\end{aligned}
$$

\subsubsection{Analisa Struktur}

Analisa struktur dimulai dengan pemodelan kombinasi pembebanan tsunami menurut FEMA P646 dan SNI 1727 yang dimasukkan ke dalam software ETABS. ETABS (Extended Three Analysis Building Systems) merupakan software yang digunakan untuk menganalisis struktur gedung terhadap beban-beban yangbekerja serta mendesain elemen-elemennya. ETABS merupakan program analisis struktur yang dikembangkan oleh perusahaan software Computers and Structures,Incorporated (CSI) yang berlokasi di Barkeley, California, Amerika Serikat[7].

Kombinasi maksimum akan menghasilkan kapasitas elemen dan reaksi tumpuan. Kapasitas elemen terdiri dari Rasio kapasitas aksial, Rasio kapasitas geser, Rasio kapasitas momen, dan Rasio gaya momen aksial. Kapasitas elemen yang digunakan adalah angka terbesar yang muncul dari beberapa kombinasi pembebanan sehingga dapat dijadikan pedoman untuk perhitungan elemen-elemen selanjutnya dan dilakukan perbandingan antara peraturan FEMA dan SNI.

\subsubsection{Analisa Prilaku Struktur}

Perilaku struktur adalah perilaku yang ditimbulkan oleh suatu bangunan akibat dari suatu gaya. Perilaku struktur tersebut adalah displacement dan simpangan antar lantai.

1. Perpindahan (Displacement)

Perpindahan terjadi akibat adanya beban yang berkerja pada titik-titik join antara elemen. Dalam teori analisis struktur pemodelan space frame, derajat kebebasan aktualnya ada 6 buah, yaitu 3 buah translasi ( $\mathrm{x}, \mathrm{y}$, dan $\mathrm{z}$ ) yang menghasilkan perpindahan (displacement) 3 $\operatorname{arah}(\mathrm{x}, \mathrm{y}$, dan $\mathrm{z})$, dan 3 buah rotasi $(\mathrm{x}, \mathrm{y}$, dan $\mathrm{z})$ yang menghasilkan momen dalam arah $(\mathrm{x}, \mathrm{y}$, dan z) (Ningsih, 2011).
2. Simpangan Antar Lantai (Story Drift)

Penentuan simpangan antar lantai $(\Delta)$ harus hitung sebagai perbedaan defleksi pada pusat massa tingkat teratas dan terbawah yang ditinjau, seperti pada gambar 3 .

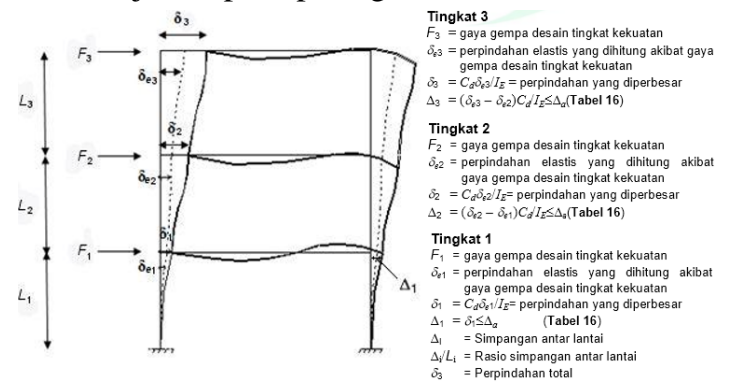

Gambar 3 Simpangan Antar Lantai

Sumber : [8]

Analisa perilaku struktur dilakukan setelah mendapatkan hasil analisa struktur dari pemodelan gedung. Kemudian diambil nilai-nilai perilaku strukturnya antara lain perpindahan (displacement) dan simpangan antar lantai (story drift). Selanjutnya dari nilai-nilai perilaku struktur tersebut dilakukan perbandingan nilai nominalnya berdasarkan FEMA dan SNI.

\section{Hasil dan Pembahasan}

\subsection{Hasil}

\subsubsection{Hasil Perhitungan Gaya Beban Tsunami}

Hasil perhitungan Gaya yang digunakan pada pemodelan gedung control room terhadap beban tsunami menurut peraturan FEMA dan SNI sebagai berikut :

Tabel 1 Hasil Gaya Beban Tsunami

\begin{tabular}{lcc}
\hline \multirow{1}{*}{ Gaya } & \multicolumn{2}{c}{ Hasil Perhitungan } \\
\cline { 2 - 3 } & FEMA & SNI \\
Hidrostatik & $95,601 \mathrm{kN}$ & $9,745 \mathrm{kN}$ \\
\hline Hidrodinamik & $\mathrm{K} 1.2,704 \mathrm{kN}$ & $\mathrm{K} 1.2,704 \mathrm{kN}$ \\
Tumbukan Debris & $\mathrm{K} 2.3,154 \mathrm{kN}$ & $\mathrm{K} 2.3,154 \mathrm{kN}$ \\
Tahanan Debris & $283,847 \mathrm{kN}$ & - \\
Impak Puing & $108,160 \mathrm{kN}$ & - \\
\hline
\end{tabular}

Pada tabel 1 dapat dilihat bahwa untuk pembebanan tsunami lebih besar terhadap peraturan SNI dari pada terhadap peraturan FEMA, karena di peraturan SNI terdapat perhitungan untuk gaya impak puing dengan nilai $323,870 \mathrm{kN}$.

Tabel 2 Jumlah Elemen Struktur Balok 
Pada tabel 2 memperlihatkan profil dan jumlah

\begin{tabular}{|c|c|c|}
\hline Balok & Profil & Jumlah Elemen \\
\hline B1 & H $150 \times 150 \times 31,5$ & 9 \\
\hline B2 & Н $200 \times 100 \times 21,3$ & 7 \\
\hline B3 & H 200x $150 \times 30,6$ & 18 \\
\hline B4 & H $250 \times 125 \times 29,6$ & 8 \\
\hline B5 & H $300 \times 200 \times 56,8$ & 3 \\
\hline B6 & H $450 \times 200 \times 76,0$ & 3 \\
\hline B7 & Н $500 \times 200 \times 79,5$ & 2 \\
\hline
\end{tabular}

elemen struktur balok yang digunakan pada gedung control room.

Tabel 3 Jumlah Elemen Struktur Kolom

Pada tabel 3 memperlihatkan profil dan jumlah

\begin{tabular}{ccc}
\hline Kolom & Profil & Elemen \\
\hline K1 & H 250x250x72,4 & 17 \\
K2 & H 200x200x49,2 & 2 \\
\hline
\end{tabular}

elemen struktur kolom yang digunakan pada gedung control room.

Tabel 4 Jumlah Elemen Struktur Pelat Lantai

\begin{tabular}{cc}
\hline Pelat Lantai & Elevasi $(\mathbf{m})$ \\
\hline PL0 & 0 \\
PL1 & 3,95 \\
PL2 & 5,70 \\
\hline
\end{tabular}

Pada tabel 4 memperlihatkan elevasi struktur pelat lantai yang digunakan pada gedung control room.

\subsubsection{Rasio kapasitas \\ 3.1.2.1 Rasio kapasitas aksial}

Rasio kapasitas gaya aksial maksimum balok dari kedua peraturan terdapat pada $\mathrm{B} 2$ dengan profil $\mathrm{H}$ $\mathrm{H} 200 \times 100 \times 21,2$. Pada peraturan FEMA dan SNI rasio kapasitas aksial maksimum adalah 0,05. Pada kedua peraturan dapat juga dilihat bahwa pada balok B1, B5, B6 dan B7 rasio kapasitas gaya aksial adalah 0 .

Pada kolom diperoleh rasio kapasitas aksial maksimum dari kedua pemodelan adalah adalah pada K1 dengan profil $\mathrm{H} 250 \times 250 \times 72,4$ dan minimum pada $\mathrm{K} 2$ dengan profil H $200 \times 200 \times 49,9$. Pada peraturan FEMA rasio kapasitas aksial maksimum adalah 0,12 dan minimum adalah 0,01 , sedangkan pada peraturan SNI maksimumnya adalah 0,10 dan minimumnya adalah 0,01 .

\subsubsection{Rasio kapasitas geser}

Besaran gaya momen maksimum pada balok yang diperoleh dari peraturan fema adalah pada B2 dengan profil H $200 \times 100 \times 21,3$. Sedangkan dari peraturan SNI bahwa besaran gaya momen maksimum pada balok yang diperoleh adalah pada B6 dengan profil H 450×200×76,0. Pada peraturan FEMA gaya momen maksimum adalah $0,16 \mathrm{kN}$, sedangkan pada peraturan SNI gaya momen maksimum adalah 0,15 kN. Pada kedua peraturan dapat juga dilihat bahwa pada balok B3 rasio kapasitas gaya momen adalah 0 .
Pada balok diperoleh rasio kapasitas geser maksimum dari kedua pemodelan adalah adalah pada K1 dengan profil $\mathrm{H} 250 \times 250 \times 72,4$ dan minimum pada $\mathrm{K} 2$ dengan profil $\mathrm{H} 200 \times 200 \times 49,9$. Pada peraturan FEMA rasio kuat geser maksimum adalah 1,26 dan minimum adalah 0,02, sedangkan pada peraturan SNI maksimumnya adalah 1,04 dan minimumnya adalah 0,01 .

Pada plat lantai besaran rasio kapasitas gaya geser pelat lantai pada peraturan FEMA dan SNI PL1 adalah 0,25 dan PL2 sebesar 0,17.

\subsubsection{Rasio kapasitas momen}

Rasio kapasitas momen maksimum dan minimum pada balok yang diperoleh dari kedua peraturan adalah pada B6 dengan profil $\mathrm{H} 450 \times 200 \times 76,0$ dan B3 dengan profil $\mathrm{H} 200 \times 150 \times 30,6$. Pada peraturan FEMA rasio kapasitas momen maksimum adalah 0,26 $\mathrm{kN}$ dan minimum adalah $0,02 \mathrm{kN}$, sedangkan pada peraturan SNI rasio kapasitas momen maksimum adalah $0,25 \mathrm{kN}$ dan minimum adalah $0,02 \mathrm{Kn}$

Pada kolom rasio kapasitas momen maksimum dari kedua pemodelan adalah adalah pada $\mathrm{K} 1$ dengan profil $\mathrm{H} 250 \times 250 \times 72,4$ dan minimum pada $\mathrm{K} 2$ dengan profil H $200 \times 200 \times 49,9$. Pada peraturan FEMA rasio kapasitas momen maksimum adalah 0,56 dan minimum adalah 0,05 , sedangkan pada peraturan SNI maksimumnya adalah 0,45 dan minimumnya adalah 0,04 .

Besaran rasio kapasitas momen arah $\mathrm{x}$ pelat lantai pada peraturan FEMA dan SNI PL1 adalah 0,54 dan PL2 sebesar 0,48. besaran rasio kapasitas momen arah y pelat lantai pada peraturan FEMA PL1 adalah 0,39 dan PL2 sebesar 0,36, sedangkan pada peraturan SNI rasio kapasitas pada PL1 adalah 0,38 dan PL2 sebesar 0,36 .

\subsubsection{Rasio gaya momen aksial}

Rasio gaya momen aksial maksimum dan minimum pada balok yang diperoleh dari kedua peraturan adalah pada B2 dengan profil $\mathrm{H} 200 \times 100 \times 21,3$ dan B3 dengan profil H $200 \times 150 \times 30,6$. Pada peraturan FEMA rasio gaya momen aksial maksimum adalah 0,28 $\mathrm{kN}$ dan minimum adalah $0,03 \mathrm{kN}$, sedangkan pada peraturan SNI rasio gaya momen aksial maksimum adalah $0,25 \mathrm{kN}$ dan minimum adalah $0,03 \mathrm{Kn}$.

Besaran nilai maksimum dan minimum rasio gaya momen aksial yang diperoleh pada kolom terdapat pada $\mathrm{K} 1$ dengan profil $\mathrm{H} 250 \times 250 \times 72$, untuk peraturan FEMA dan SNI adalah 0,59 dan 0,48. Pada peraturan FEMA dan SNI untuk kolom $\mathrm{K} 2$ dengan profil $\mathrm{H}$ $200 \times 200 \times 49,9$ nilai rasio kapasitas yang diperoleh adalah 0,05 dan 0,05 .

\subsubsection{Perilaku struktur}

3.1.3.1 Perpindahan antar lantai (Story displacement)

Nilai story displacement merupakan hasil output analisis ETABS. Nilai story displacement maksimum pada arah $\mathrm{x}$ dan $\mathrm{y}$ untuk masing-masing 
peraturan yang diperoleh dapat dilihat pada Tabel 5 berikut.

Tabel 5 Hasil Story Displacement

\begin{tabular}{|c|c|c|c|c|}
\hline \multirow{2}{*}{$\begin{array}{l}\text { Plat } \\
\text { lantai }\end{array}$} & \multicolumn{2}{|c|}{$\begin{array}{c}\begin{array}{c}\text { Displacement Arah X } \\
(\mathrm{mm})\end{array} \\
\end{array}$} & \multicolumn{2}{|c|}{$\begin{array}{c}\begin{array}{c}\text { Displacement Arah Y } \\
(\mathrm{mm})\end{array} \\
\end{array}$} \\
\hline & FEMA & SNI & FEMA & SNI \\
\hline PL0 & 0 & 0 & 0 & 0 \\
\hline PL1 & 0,24 & 0,22 & 0,68 & 0,61 \\
\hline PL2 & 0,20 & 0,20 & 0,57 & 0,50 \\
\hline
\end{tabular}

\subsubsection{Simpangan antar lantai (Story drift)}

Berdasarkan SNI 1726:2019 untuk menentukan simpangan antar lantai ditentukan dengan mengalikan perpindahan dengan $\mathrm{Cd} / \mathrm{Ie}$ yang mana nilai faktor pembesaran defleksi (Cd) untuk SRPMK adalah 5,5. Hasil perhitungan simpangan antar lantai dapat dilihat pada Tabel 6 dan Tabel 7 berikut.

Tabel 6 Hasil Simpangan Antar Lantai Peraturan FEMA

\begin{tabular}{|c|c|c|c|c|c|c|}
\hline $\begin{array}{c}\text { Plat } \\
\text { Lantai }\end{array}$ & $\begin{array}{l}\text { Tinggi } \\
(\mathbf{m m})\end{array}$ & Arah & $\begin{array}{l}\text { Displacement } \\
(\mathbf{m m})\end{array}$ & $\begin{array}{c}\delta \\
(\mathbf{m m})\end{array}$ & $\underset{(\mathbf{m m})}{\Delta}$ & $\begin{array}{c}\Delta \text { izin }= \\
0,020 \times H \\
(\mathrm{~mm})\end{array}$ \\
\hline \multirow{2}{*}{ PL2 } & \multirow{2}{*}{1750} & $X$ & 0,20 & 1,10 & 0,22 & 35,00 \\
\hline & & $\mathrm{Y}$ & 0,57 & 3,14 & 0,61 & 35,00 \\
\hline \multirow{2}{*}{ PL1 } & \multirow{2}{*}{3950} & $X$ & 0,24 & 1,32 & 1,32 & 79,00 \\
\hline & & $\mathrm{Y}$ & 0,68 & 3,74 & 3,74 & 79,00 \\
\hline \multirow{2}{*}{ PL0 } & \multirow[b]{2}{*}{0} & $X$ & 0,00 & 0,00 & 0,00 & 0,00 \\
\hline & & $\mathrm{Y}$ & 0,00 & 0,00 & 0,00 & 0,00 \\
\hline
\end{tabular}

Tabel 7 Hasil Simpangan Antar Lantai Peraturan SNI

\begin{tabular}{ccccccc}
\hline $\begin{array}{c}\text { Plat } \\
\text { Lantai }\end{array}$ & $\begin{array}{c}\text { Tinggi } \\
(\mathbf{m m})\end{array}$ & Arah & $\begin{array}{c}\text { Displacement } \\
(\mathbf{m m})\end{array}$ & $\begin{array}{c}\boldsymbol{\delta} \\
(\mathbf{m m})\end{array}$ & $\begin{array}{c}\Delta \\
(\mathbf{m m})\end{array}$ & $\begin{array}{c}\Delta \mathbf{\Delta i z i n}= \\
\mathbf{0 , 0 2 0 x H} \\
(\mathbf{m m})\end{array}$ \\
\hline \multirow{2}{*}{ PL2 } & \multirow{2}{*}{1750} & $\mathrm{X}$ & 0,20 & 1,10 & 0,11 & 35,00 \\
\cline { 3 - 7 } & $\mathrm{Y}$ & 0,50 & 2,75 & 0,61 & 35,00 \\
\hline \multirow{2}{*}{ PL1 } & \multirow{2}{*}{3950} & $\mathrm{X}$ & 0,22 & 1,21 & 1,21 & 79,00 \\
\cline { 3 - 7 } PL0 & \multirow{2}{*}{0} & $\mathrm{Y}$ & 0,61 & 3,36 & 3,36 & 79,00 \\
\cline { 3 - 7 } & & $\mathrm{Y}$ & 0,00 & 0,00 & 0,00 & 0,00 \\
\hline
\end{tabular}

\subsection{Pembahasan}

\subsubsection{Kapasitas elemen}

Menurut kedua peraturan rasio maksimum tiap gaya-gaya dalam balok masih aman untuk gedung. Rasio terbesar terletak pada gaya momen pada peraturan FEMA dengan nilai 0,26 dan pada peraturan SNI dengan nilai 0.25 .

Pada peraturan FEMA dan SNI rasio maksimum gaya aksial dan gaya momen pada kolom masih aman untuk gedung. Tetapi untuk gaya geser pada kedua peraturan sudah tidak aman untuk gedung. Rasio terbesar terletak pada gaya geser dengan nilai menurut peraturan FEMA adalah 1,26 dan untuk peraturan SNI adalah 1,04 .

Nilai rasio maksimum menurut peraturan FEMA dan SNI tiap gaya-gaya dalam pelat lantai masih aman untuk gedung. Rasio terbesar kedua perraturan terletak pada gaya momen dengan nilai 0.54 .

Nilai rasio maksimum untuk balok dan kolom masih memenuhi persyaratan interaksi gaya momen aksial. Rasio terbesar kedua peraturan terletak pada kolom dengan nilai 0,59 dan 0,48 .

\subsubsection{Perilaku struktur}

3.2.2.1 Perpindahan antar lantai (Story displacement)

Nilai story displacement arah $\mathrm{x}$ pada peraturan FEMA dan SNI. Pada kedua peraturan nilai displacement maksimum terjadi pada elevasi 3,950 m dengan besaran 0,24 mm untuk peraturan FEMA dan 0.22 untuk peraturan SNI

Nilai story displacement arah y pada peraturan FEMA dan SNI. Pada kedua peraturan nilai displacement maksimum terjadi pada elevasi 3,950 $\mathrm{m}$ dengan besaran 0,68 mm untuk peraturan FEMA dan 0,61 untuk peraturan SNI.

\subsubsection{Simpangan antar lantai (Story drift)}

Nilai simpangan antar lantai arah $\mathrm{x}$ untuk kedua peraturan tidak melebihi nilai izin. Nilai simpangan antar lantai maksimum berada pada elevasi 3,950 m, untuk peraturan FEMA sebesar $1,32 \mathrm{~mm}$ dan untuk peraturan SNI sebesar 1,21 mm.

Nilai simpangan antar lantai arah y untuk kedua peraturan tidak melebihi nilai izin. Nilai simpangan antar lantai maksimum berada pada elevasi 3,950 m, untuk peraturan FEMA sebesar 3,74 mm dan untuk peraturan SNI sebesar 5,02 mm

\section{Kesimpulan dan saran}

Berdasarkan hasil pengolahan data serta pembahasan dapat diambil beberapa kesimpulan dan saran sebagai hasil akhir dari penelitian ini.

\subsection{Kesimpulan}

Hasil Rasio kapasitas elemen struktur kolom, balok dan plat lantai terhadap beban tsunami menurut FEMA dan SNI masih memenuhi. Namun pada struktur kolom yang terletak paling depan menerima beban tsunami terbesar dengan nilai rasio 1,26 pada peraturan FEMA dan rasio 1,04 pada peraturan SNI dengan profil $\mathrm{H}$ 250x250x72,4 berjumlah 3 elemen kolom sehingga pada kolom tersebut sudah tidak aman.

Hasil analisa Perilaku struktur berupa story displacement dan story drift yang diperoleh dari kedua peraturan masih aman dari kedua arah $\mathrm{x}$ dan y karena tidak melewati batas yang diizinkan.

\subsection{Saran}

Adapun saran untuk penelitian selanjutnya yaitu melakukan kajian terhadap daya dukung pondasi dikarenakan adanya penambahan beban tsunami sesuai dengan FEMA P646 dan SNI 1727:2020 untuk meninjau apakah pondasi eksisting masih aman untuk dipertahankan dan pengguna bangunan dapat mencari rekomendasi perbaikan supaya fungsional gedung aman terhadap pembebanan-pembebanan sesuai FEMA dan SNI. 


\section{Daftar Pustaka}

[1] Technical Data Book Volume 25 Book 1 of 2 Buildins Unit 68, PT. Arun NGL, 1973

[2] Syamsidik, T. M. Rasyif, dan S. Kato, 2015. Development Of Accurate Tsunami Estimated Times Of Arrival For Tsunami-Prone Cities In Aceh, Indonesia, International Journal of Disaster Risk Reduction 14: 403..

[3] Federal Emergency Management Agency. 2012. Guidelines for Design of Structures for Vertical Evacuation from Tsunami Second Edition. Department of Homeland Security FEMA Mitigation Division: Washington D.C.

[4] Badan Standar Nasional. 2020. Standar Nasional Indonesia (SNI 1727:2020) tentang Beban minimum untuk perancangan bangunan gedung dan struktur lain, Departemen Pekerjaan Umum.

[5] Faqih. A, 2015. Studi Alternatif Perencanaan Strukur Komposit pada Gedung Kantor Dermaga Multipurpose Tanjung Perak Surabaya, Jurnal Rekayasa Sipil Vol.3 No.2, Universitas Islam Malang, 2015.

[6] Badan Standar Nasional, 2020. Standar Nasional Indonesia (SNI 1729:2020) tentang Spesifikasi untuk Bangunan Gedung Baja Struktural, Departemen Pekerjaan Umum.

[7] Marwan. M.U, 2020. Evaluasi Perilaku Struktur Bangunan Gedung Berdasarkan Standar Perencanaan Terbaru di Kota Banda Aceh (disertai Perubahan SNI 1726, SNI 1727, dan SNI 2847), Tugas Sarjana, Jurusan Teknik Sipil Unsyiah.

[8] Badan Standar Nasional, 2019. Standar Nasional Indonesia (SNI 1726:2019) tentang Tata Cara Perencanaan Ketahanan Gempa untuk Struktur Bangunan Gedung dan Non Gedung, Departemen Pekerjaan Umum. 